\title{
Tree resin as a cultivation strategy under water deficit ${ }^{1}$
}

\author{
Amanda Maria Leal Pimenta 2 , Silvânio Rodrigues dos Santos², \\ Nelson de Abreu Delvaux Júnior ${ }^{2}$, Marcos Koiti Kondo², Ignacio Aspiazú ${ }^{2}$
}

\section{ABSTRACT}

The search for alternatives that enable the improvement of the soil water retention capacity should focus on a better water use by cultivated plants. This study aimed to evaluate the effect of natural tree resin rates and irrigation levels on the cotton (intermediate cycle) and wild radish (short cycle) crops. Two experiments were conducted in a completely randomized design, in a $5 \times 5$ factorial arrangement, with three replications and five tree resin rates $\left(0,0.67,1.33,2.00\right.$ and $\left.2.67 \mathrm{~g} \mathrm{plant}^{-1}\right)$, five soil water tensions $(15,30,45,60$ and $75 \mathrm{kPa})$ for cotton plants and five irrigation water levels $(40,60,80,100$ and $120 \%$ of the ETc) for wild radish plants. The plant height, stem diameter and number of leaves were evaluated at 93 days after sowing (DAS) for the cotton plants; while the plant height, root diameter and number of leaves were evaluated at 30 DAS for the wild radish plants, as well as quantified the shoot and root dry weights of both plant species. The application of tree resin reduces the susceptibility of the crop to water deficit, being $2.7 \mathrm{~g} \mathrm{plant}^{-1}$ the highest recommended rate to improve the plant development. The use of tree resin increases the water-use efficiency in cotton and wild radish crops in up to $0.68 \mathrm{~g} \mathrm{~L}^{-1}$ and $69.6 \mathrm{~g} \mathrm{~L}^{-1}$, respectively.

KEYWORDS: Gossypium hirsutum, Raphanus raphanistrum, irrigation.

\section{INTRODUCTION}

Irrigated agriculture is responsible for $52 \%$ of the water use in Brazil (Brasil 2019). However, water is a scarce input for agricultural plant species and, consequently, for agribusiness, in semiarid regions (Villes et al. 2019). The development of technologies that increase plant yield and improve agricultural products quality is essential to obtain a greater water-use efficiency in agriculture, decrease water waste and avoid water deficit.

\section{RESUMO}

\section{Resina vegetal como estratégia de cultivo sob déficit hídrico}

Alternativas que possibilitem a melhoria da retenção de água no solo devem ser buscadas visando maior aproveitamento de água por plantas cultivadas. Objetivou-se avaliar o efeito de doses de resina vegetal natural e estratégias de irrigação nas culturas do algodão (ciclo intermediário) e rabanete (ciclo curto). Foram desenvolvidos dois experimentos, em fatorial 5 x 5, em delineamento inteiramente casualizado, com três repetições e cinco doses de resina vegetal $\left(0 ; 0,67 ; 1,33 ; 2,00 ;\right.$ e 2,67 g planta $\left.^{-1}\right)$, cinco tensões de água no solo $(15 ; 30 ; 45 ; 60 ;$ e $75 \mathrm{kPa})$ para o algodoeiro e cinco reposições de água (40; 60; 80; 100; e 120 \% da ETc) para o rabanete. Aos 93 dias após a semeadura (DAS), foram avaliados a altura, diâmetro de caule e número de folhas do algodoeiro. Aos 30 DAS, foram medidos a altura, diâmetro de raiz e número de folhas do rabanete, bem como quantificada a matéria seca da parte aérea e das raízes de ambas as culturas. A resina vegetal reduz a suscetibilidade da cultura ao déficit hídrico, com a dose máxima de $2,7 \mathrm{~g}_{\text {planta }}{ }^{-1}$ sendo recomendada para se obter melhor desenvolvimento das plantas. A resina aumenta a eficiência do uso de água nas culturas de algodão e rabanete, correspondendo a até $0,68 \mathrm{~g} \mathrm{~L}^{-1}$ e $69,6 \mathrm{~g} \mathrm{~L}^{-1}$, respectivamente.

PALAVRAS-CHAVE: Gossypium hirsutum, Raphanus raphanistrum, irrigação.

The application of water-retaining hydrogels to areas close to the plant roots is an alternative to mitigate the effects of water deficit by decreasing water consumption in agricultural areas, since they act as reservoirs, making water available to plants (Lopes et al. 2017).

Positive results can be obtained with the use of low rates of these polymers, which can improve the water and nutrient retention in the substrate, making it an alternative for seedling production (Hafle et al. 2008).

\footnotetext{
${ }^{1}$ Received: Feb. 26, 2021. Accepted: May 31, 2021. Published: July 20, 2021. DOI: 10.1590/1983-40632021v5167901.

${ }^{2}$ Universidade Estadual de Montes Claros, Departamento de Ciências Agrárias, Janaúba, MG, Brasil.

E-mail/ORCID: amandalea190@hotmail.com/0000-0001-5827-8193; silvanio.santos@unimontes.br/0000-0003-0245-9184; nelson.junior@unimontes.br/0000-0003-4125-3744; marcos.kondo@unimontes.br/0000-0001-6875-4907; ignacio.aspiazu@unimontes.br/0000-0002-0042-3324.
} 
The application of hydrogel in agriculture has shown promising results; however, the high price and low biodegradability of this product often make large-scale applications unviable (Bahram et al. 2016). Water-retaining polymers can be degraded by the presence of microorganisms, high temperatures, $\mathrm{pH}$ effect, ultraviolet radiation and, mainly, due to the action of salts from fertilizer application and liming (Caulfield et al. 2003). Most of these polymers are from synthetic origin (Mendonça et al. 2013) and the byproducts resulted from their degradation may be harmful to human health and plant species, due to the release of acrylamide, which is a chemical compound that is probably carcinogenic to humans, regardless of the pathway (Passauer et al. 2015).

Natural tree resins that polymerize irreversibly under high temperatures have carbon chains of three-dimensional structure (Rodriguez et al. 2014). These polymers are complex organic structures that may contain phenols, alcohols, esters, essential oils and terpene acids (ASM 2001), and present organic groups $\left(-\mathrm{OH},-\mathrm{NH}_{2},-\mathrm{COOH},-\mathrm{CONH}_{2}\right.$ and $\left.-\mathrm{SO}_{3} \mathrm{H}\right)$ in their chain structures, what contributes to a greater swelling of the material in the presence of water (Nelson \& Cox 2018).

Studies on the use of resin rates in agriculture are needed to assess its capacity to release the retained water for the development of cultivated plant species. Therefore, a short-cycle (Raphanus raphanistrum; wild radish) and an intermediate-cycle (Gossypium hirsutum; cotton) species were chosen to evaluated this tree resin, which can be rapidly degraded in the soil (Mariano-Torres et al. 2015).

Water deficits usually occur during some stages of the cotton and wild radish cycles, causing severe damages to plants; thus, this tree resin may regulate the water availability, mainly under water deficit conditions, increasing the yield of cultivated plants and minimizing production costs. Therefore, evaluating the capacity of tree resin to retain and release water to plants under different water conditions and irrigation levels may provide accurate responses to issues regarding its agricultural use.

Thus, this study aimed to determine a rate for the application of tree resin that decreases the water consumption for two cultivated plant species (cotton and wild radish), with no effects on their agronomic performance.

\section{MATERIAL AND METHODS}

The tests were conducted in a greenhouse with its top and sides protected only with an antiaphid mesh, at the Universidade Estadual de Montes Claros (Unimontes), in Janaúba, Minas Gerais state, Brazil, from June to September 2019, using the cotton cultivar DP1536B2RF and the wild radish cultivar Crimson Giant.

The average rainfall of the region is $870 \mathrm{~mm}$, the average annual temperature $24^{\circ} \mathrm{C}$, the insolation 2,700 hours per year, the average relative humidity $65 \%$ and the climate Aw tropical, characterized by dry winters, according to the Köppen classification.

The soil was classified as Eutrophic Red Latosol (Oxisol) with medium texture, specifically a Eutrustox (USDA 2014). The samples (0.0-0.20 m; Table 1) were sieved in a 4-mm mesh sieve.

Fertilizers were applied considering the results of the soil chemical analyses, using $20 \mathrm{~kg} \mathrm{ha}^{-1}$ of $\mathrm{N}$, $60 \mathrm{~kg} \mathrm{ha}^{-1}$ of $\mathrm{P}_{2} \mathrm{O}_{5}$ and $70 \mathrm{~kg} \mathrm{ha}^{-1}$ of $\mathrm{K}_{2} \mathrm{O}$ before sowing, and $60 \mathrm{~kg} \mathrm{ha}^{-1}$ of $\mathrm{N}, 40 \mathrm{~kg} \mathrm{ha}^{-1}$ of $\mathrm{P}_{2} \mathrm{O}_{5}$ and $30 \mathrm{~kg} \mathrm{ha}^{-1}$ of $\mathrm{K}_{2} \mathrm{O}$ as topdressing, totaling $100 \mathrm{~kg} \mathrm{ha}^{-1}$ of $\mathrm{P}_{2} \mathrm{O}_{5}$, $100 \mathrm{~kg} \mathrm{ha}^{-1}$ of $\mathrm{K}_{2} \mathrm{O}$ and $80 \mathrm{~kg} \mathrm{ha}^{-1}$ of $\mathrm{N}$ (CFSEMG 1999). The fertilizer sources used were simple superphosphate (3.92 $\left.\mathrm{g} \mathrm{pot}^{-1}\right)$, potassium nitrate (1.83 $\left.\mathrm{g} \mathrm{pot}^{-1}\right)$ and urea $\left(0.04 \mathrm{~g} \mathrm{pot}^{-1}\right)$ before sowing, and monoammonium phosphate $\left(0.77 \mathrm{~g} \mathrm{pot}^{-1}\right)$, potassium nitrate $\left(0.78 \mathrm{~g} \mathrm{pot}^{-1}\right)$ and urea $\left(1.15 \mathrm{~g} \mathrm{pot}^{-1}\right)$ as topdressing, which were split into 3 applications up to 60 and 25 days after sowing (DAS), respectively for the cotton and wild radish crops.

The resin was collected from silk floss trees [Ceiba speciosa (A. St.-Hil.) Ravenna] at the

Table 1. Chemical attributes of the soil used in the experiment.

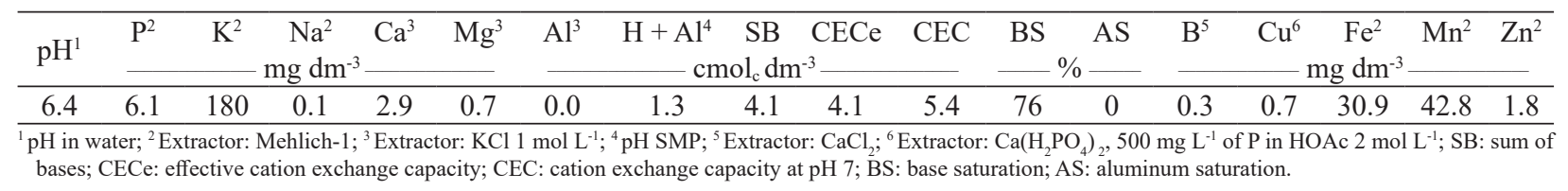


Unimontes Janaúba campus (SisGen n ${ }^{\circ}$ AA90DCC), placed in an oven at $65^{\circ} \mathrm{C}$ for 72 hours, ground and sieved (2-mm mesh). Tree resin rates were applied close to the roots of cotton and wild radish plants at 40 and 15 DAS, respectively.

Measures of soil water tensions and evapotranspiration were respectively used for cotton and wild radish plants, to evaluate their responses to the resin application under different water availability conditions, without causing losses to the plant species, as independent trials.

The experiment was conducted using 75 pots (8-L capacity) with free drainage. Five seeds were sowed per pot and the seedlings were thinned at 10 DAS, keeping three plants per pot. Tensiometers were installed in one of the replications of each treatment to quantify the water to be applied to the soil. The readings were carried out using a digital tensimeter, converting the soil water retention curve to soil moisture (Figure 1).

Daily water irrigations kept the soil moisture at field capacity, corresponding to a soil water tension of $15 \mathrm{kPa}$, based on tests of field capacity in three pots, up to 40 DAS.

The soils in the pots were saturated for three days using $4 \mathrm{~L}$ of water. They were then covered with aluminum foil to avoid evaporation and left to drain freely. After ceasing drainage, the soil of each pot was collected by using rings and, then, the soil water content was evaluated.

When $90 \%$ of the plants had more than six true leaves, at $40 \mathrm{DAS}$, the treatments with different irrigation water levels started with variable shifts, according to the soil water tension limits $(15,30$, 45, 60 and $75 \mathrm{kPa}$ ), applying the water irrigation needed to raise the soil moisture to field capacity, using five rates of resin $(0,0.67,1.33,2.00$ and $\left.2.67 \mathrm{~g} \mathrm{plant}^{-1}\right)$, considering the rate of $4 \mathrm{~g} \mathrm{pot}^{-1}$ of hydrogel $\left(4 \mathrm{~g} \mathrm{pot}^{-1} \div 3\right.$ plants pot $\left.{ }^{-1}=1.33 \mathrm{~g} \mathrm{plant}^{-1}\right)$ recommended by Mendonça et al. (2013), since no studies using tree resins were found. The powdered resin was incorporated to the soil, distributed next to the root system of the plants at approximately $2 \mathrm{~cm}$ depth. Thus, the treatments were evaluated in a $5 \times 5$ factorial arrangement, using a completely randomized experimental design, with three replications.

The plant height, stem diameter $(2 \mathrm{~cm}$ above the ground level) and number of leaves per cotton plant were evaluated at $93 \mathrm{DAS}$, due to the beginning of senescence of the plants in the treatment with the lowest water level $(75 \mathrm{kPa})$. The shoot and root dry weights were determined after drying these plant parts in an oven at $65 \pm 2{ }^{\circ} \mathrm{C}$, for 72 hours (Rodrigues 2010). The dry matter weights, obtained in g plant $^{-1}$, were transformed to percentage of total dry matter. The water-use efficiency was determined by dividing the shoot dry weight by the accumulated water volume applied.

The experiment was conducted using 75 8-L pots. Five seeds were sowed per pot, and the seedlings were thinned at $10 \mathrm{DAS}$, keeping three plants per pot. Daily water irrigations were carried out up to 15 DAS, applying $100 \%$ of the ETc, obtained by multiplying the reference evapotranspiration $\left(\mathrm{ET}_{0}\right)$

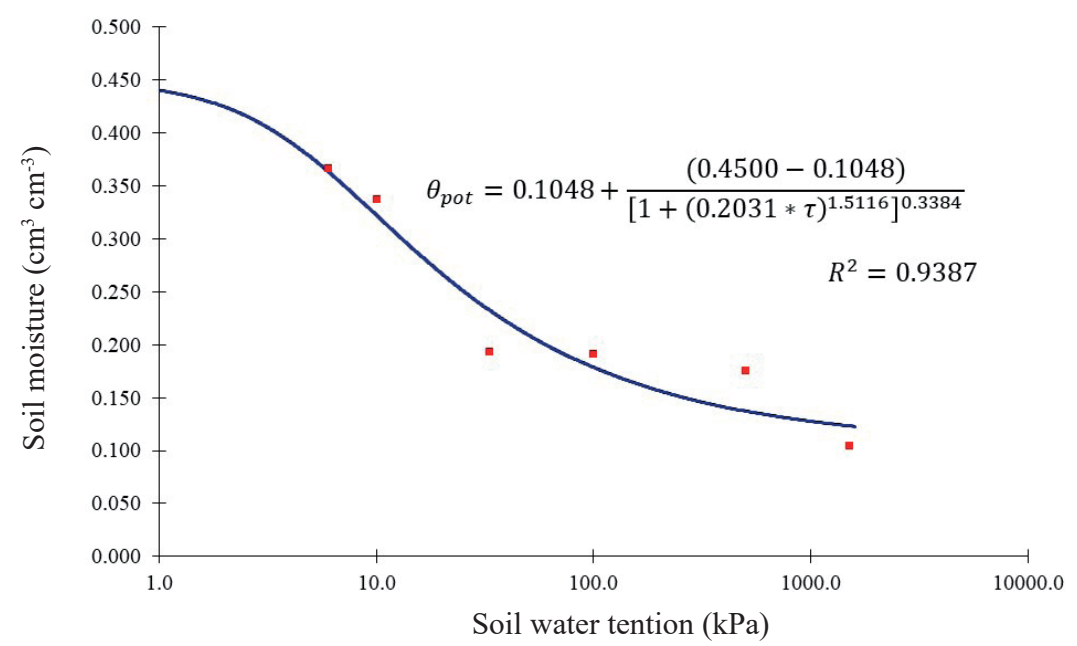

Figure 1. Soil water retention curve of the experimental area fitted to the van Genuchten model. The soil density $\left(1.59 \mathrm{~g} \mathrm{~cm}^{-3}\right)$ in the pots was determined using the volumetric ring method. 
by the crop coefficient (Kc) (Bernardo et al. 2019). $\mathrm{The}_{0} \mathrm{ET}_{0}$ was determined by the Penman-Monteith FAO model (Allen et al. 2006), using weather data from a meteorological station next to the experimental area. After 15 DAS, daily irrigations were carried out using five irrigation water levels $(40,60,80,100$ and $120 \%$ of the crop evapotranspiration - ETc), considering that an evapotranspiration of $40 \%$ is a water deficit condition. Five rates of powdered resin were applied $\left(0,0.67,1.33,2.00\right.$ and 2.67 g plant $\left.^{-1}\right)$ in a $5 \times 5$ factorial arrangement, using a completely randomized experimental design, with three replications. The resin was incorporated to the soil next to the plant roots, at approximately $2 \mathrm{~cm}$ depth.

The root length and diameter and number of leaves per plant were evaluated at $30 \mathrm{DAS}$, which correspond to the end of the plant cycle.

The plant parts were dried in an oven at $55 \pm$ $2{ }^{\circ} \mathrm{C}$, for 72 hours, to evaluate the shoot and root dry weights; and the water-use efficiency was evaluated as for the cotton plants.

The data obtained in the evaluations of the two experiments were subjected to multiple regression analysis, with coefficients evaluated by the test $(\alpha=$ 0.05 ), using the Sisvar statistical software (Ferreira 2019), and response surface graphs were developed in the Sigma Plot 14 (trial version).

\section{RESULTS AND DISCUSSION}

The effect of the interaction between resin application and soil water tension was significant for the plant height, stem diameter and number of leaves of cotton plants, fitting to quadratic polynomial models (Figures 2A-C).

The variables presented an increasing response as the resin rate was increased (Figures $2 \mathrm{~A}-\mathrm{C}$ ). This effect occurred because the resin retained most of the water applied to the soil and released it slowly to the plants, maintaining the soil moisture and making the water available to plants for longer.

The plant height, stem diameter and number of leaves of cotton plants increased as the resin rate was increased up to $2.7 \mathrm{~g} \mathrm{plant}^{-1}$ and the soil water tension up to $75 \mathrm{kPa}$, with the highest values being $31.8 \mathrm{~cm}$ (plant height), $5.7 \mathrm{~mm}$ (stem diameter) and 4 (leaves per plant). These increases were due to the water supply, which induced plant growth. According to Cordão Sobrinho et al. (2007), water deficiency reduces the stem diameter and plant height.
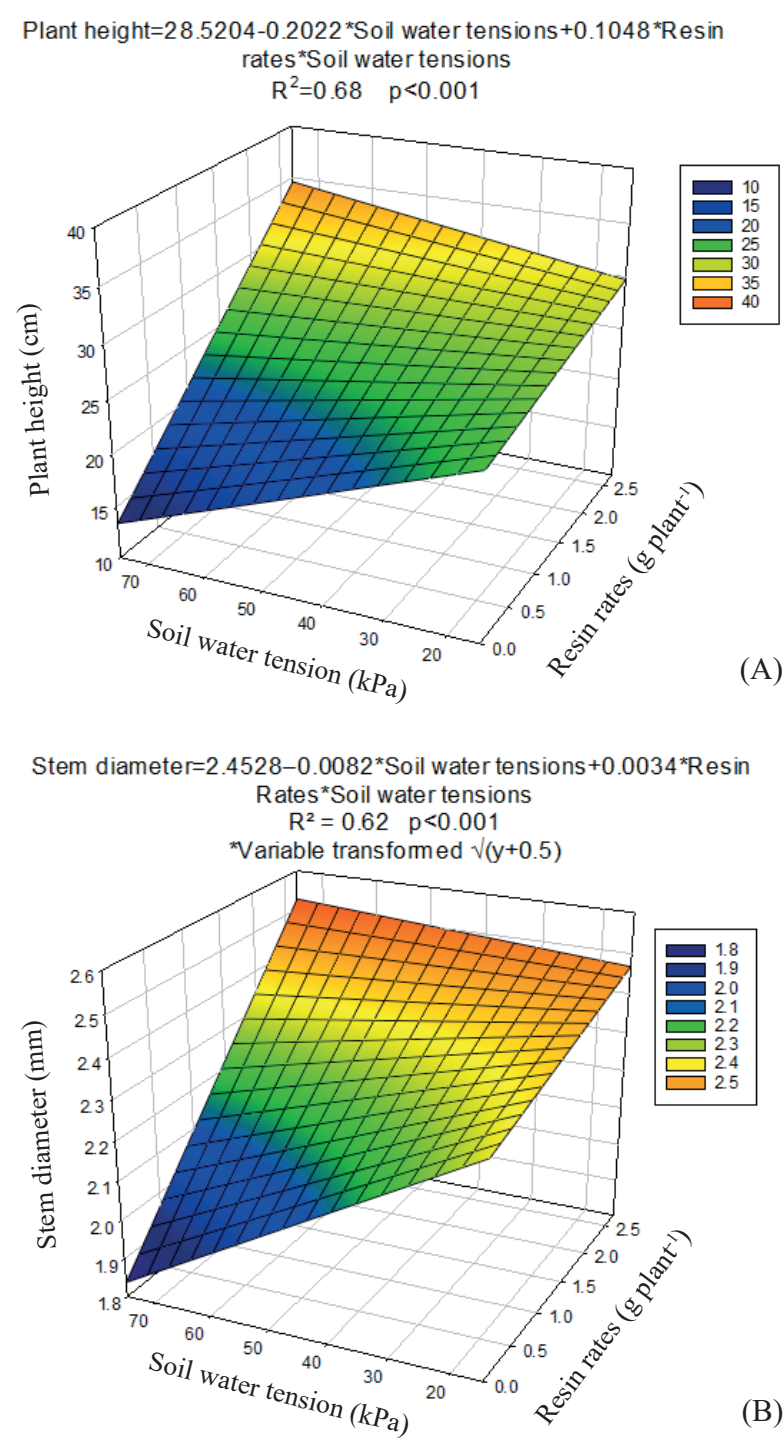

Number of leaves $=4.0088+0.1514^{*}$ Resin rates ${ }^{2}-0.0768^{*}$ Soil water tensions $+0.0009^{*}$ Soil water tensions ${ }^{2}$ $\mathrm{R}^{2}=0.59 \quad \mathrm{p}<0.001$

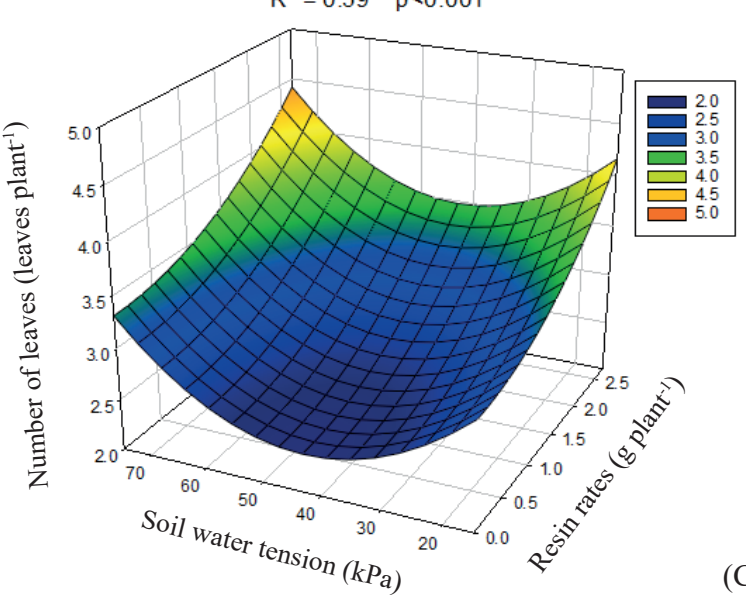

Figure 2. Plant height (A), stem diameter (B) and number of leaves $(\mathrm{C})$ of cotton plants, as a function of resin rates and soil water tensions. 
Under lower resin rates, the water deficit may have decreased cell expansion and division, affecting the enzymatic functioning and photosynthesis, triggering cell damages and, consequently, decreasing plant development (Flowers et al. 2014).

These results were attributed to increases in the soil water retention capacity caused by the incorporation of the plant polymer. Fan et al. (2015) and M'Barki et al. (2019) used a starch-based absorbent polymer to the substrate and hydrogel for spinach and olive crops and also found increases in plant height, stem diameter and fresh and dry weights, mainly under water deficit conditions. They attributed the results to a high water volume absorption and retaining of these polymers, which are reticulated macromolecules with hydrophilic groups that can significantly improve the soil water storage and availability in the plant root zone, decreasing harmful effects of water stress on plants.

The number of leaves per plant increased as the resin rate was increased, combined with water deficit (Figure 2C). This can be explained by the resin capacity to retain water and, subsequently, make it available to plants (Marques \& Bastos 2010).

The root length and diameter and number of leaves of wild radish plants were higher when using the highest resin rate $\left(2.7 \mathrm{~g} \mathrm{plant}^{-1}\right)$ and the lowest irrigation water level (40\% of the ETc), reaching $3.8 \mathrm{~cm}, 2.7 \mathrm{~cm}$ and 7 leaves plant ${ }^{-1}$, respectively (Figures $3 \mathrm{~A}-\mathrm{C}$ ). The use of resin rates below $2.7 \mathrm{~g} \mathrm{plant}^{-1}$ resulted in lower values.

According to Silva et al. (2011), the plant growth is dependent on cell division, followed by expansion, under enough amount of water. Thus, the use of resin favored the supplying of the plant water requirements using lower water volumes, promoting a better plant development.

The resin application increased the root growth and number of leaves of wild radish plants, even in the treatment with $40 \%$ of the ETc. However, according to Alves et al. (2019), the soil moisture should be maintained high, close to the field capacity, over the wild radish cycle, to obtain good yields. The resin maintained the soil at field capacity with no effects on the plant root morphology and physiology, even under irrigation water deficit conditions (40\% of the ETc), as also observed by Silva et al. (2017).

Different results were reported by Oliveira et al. (2014), who used hydrogel for growth of wild radish plants and found no significant differences
Root length $=2.2509+0.7663^{\star} R$ esin rates $-0.0044^{\star}$ Resin rates ${ }^{*} E T C$ $R^{2}=0.71 \quad p<0.001$
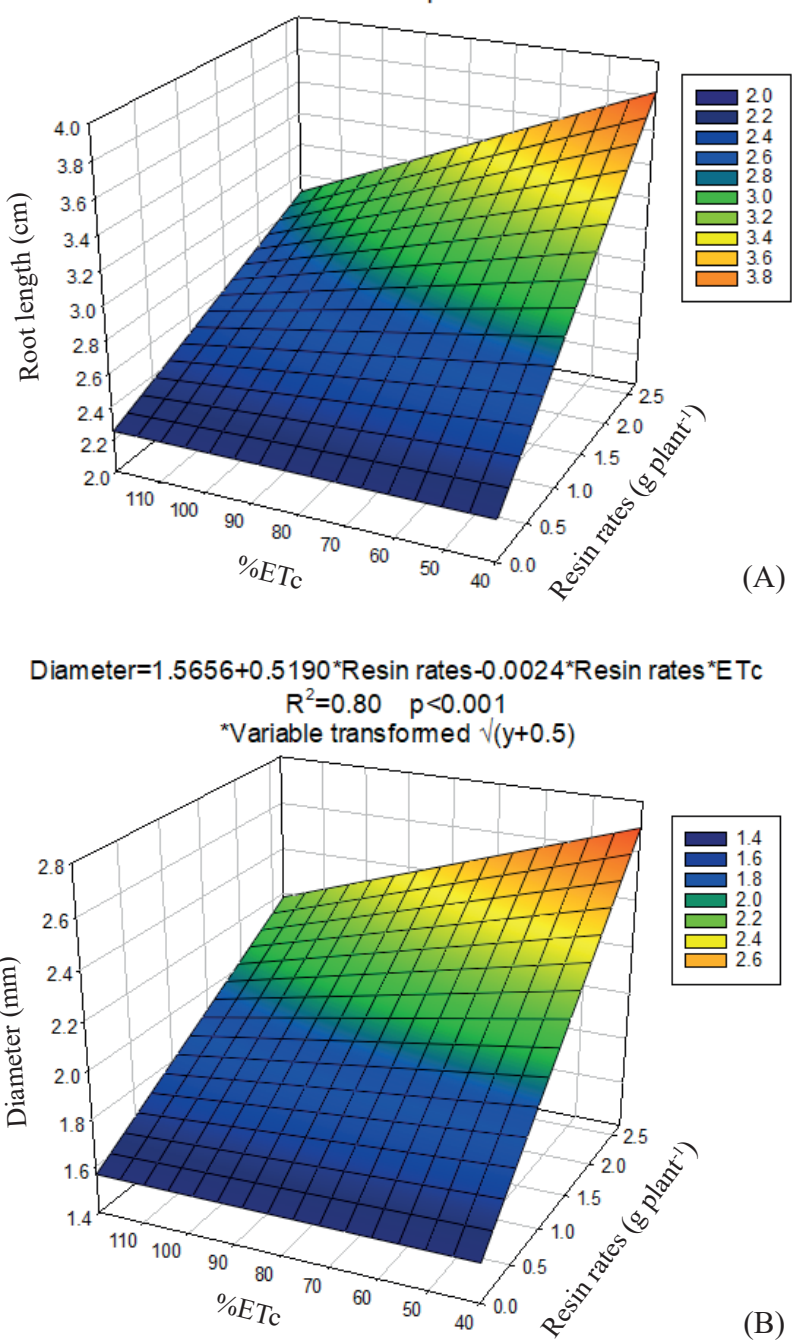

Number of leaves $=6.6380+0.0622^{*}$ Resin rates ${ }^{2}-0.00004^{*} \mathrm{ETC}^{2}$ $R^{2}=0.40 \quad p<0.005$

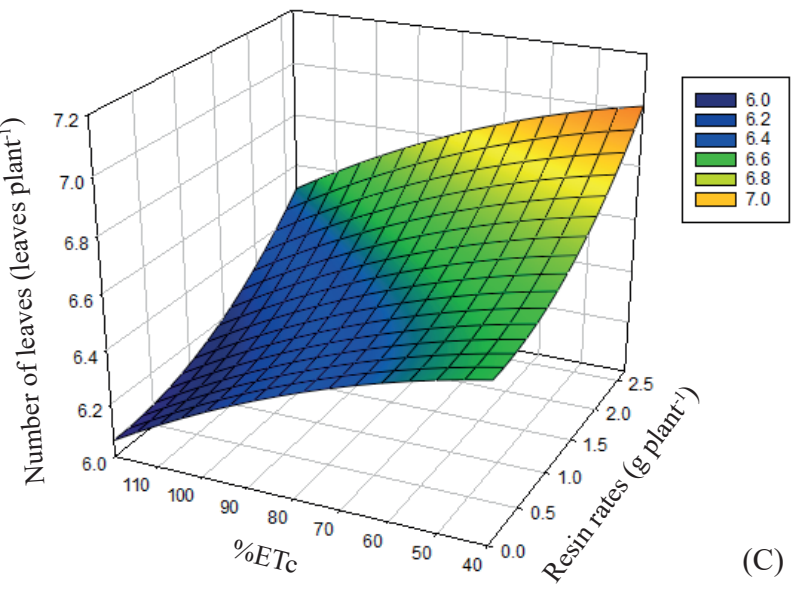

Figure 3. Root length (A) and diameter (B) and number of leaves $(C)$ of wild radish plants, as a function of tree resin rates and irrigation levels based on the crop evapotranspiration (\% ETc). 
in length and number of leaves, total fresh weight, shoot fresh weight and tuber fresh weight, probably because the hydrogel decreased the soil permeability (Coelho et al. 2008).

The interaction between resin rate and soil water tension was significant for the shoot and root dry weights of cotton plants (Figures 4A and 4C), as well as the interaction between resin rate and crop evapotranspiration (ETc) for shoot and root dry weights of wild radish plants (Figures 4B and 4D), with an increasing response as the resin rate was increased.

The high shoot and root dry weights of the evaluated plant species were due to the optimization of water availability by the presence of the plant polymer, which improved the soil aeration and drainage, accelerating the development of the plant root and shoot systems, as also reported by Azevedo et al. (2002).

In the present study, using resin rates, the results were similar to those reported by Zomerfeld et al. (2021), who obtained a better development of radish when they used hydrogel, because the polymer allows a greater efficiency in the use of water.

The root dry weight presented a good response to the use of resin for both the plant species evaluated (Figures 4C and 4D). Root dry weight is important for the plant development, because a good rooting results in plants with higher potential for growth and survival in the field (Eloy et al. 2013).

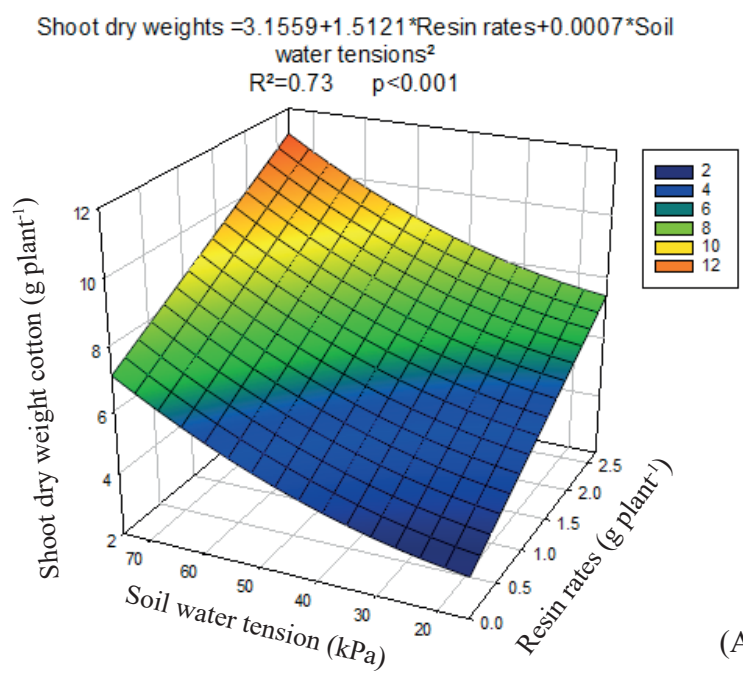

(A)

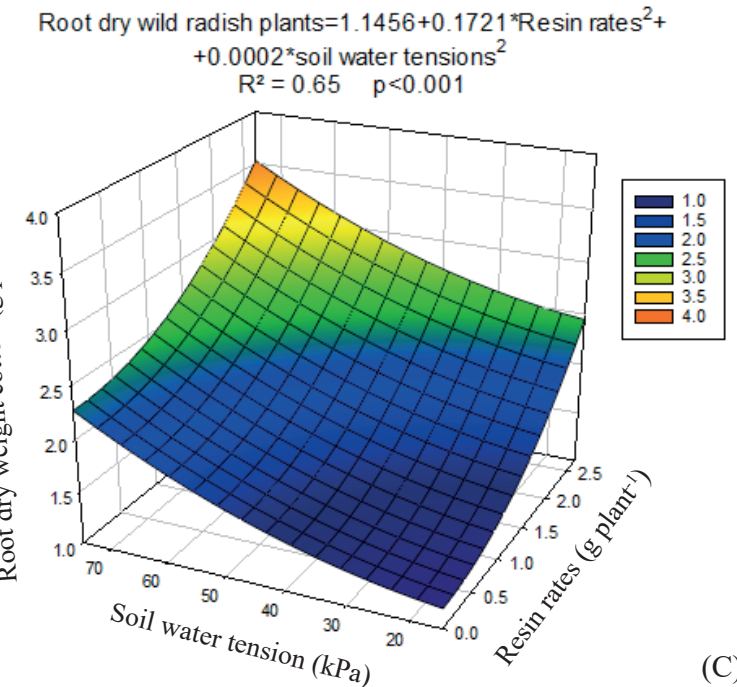

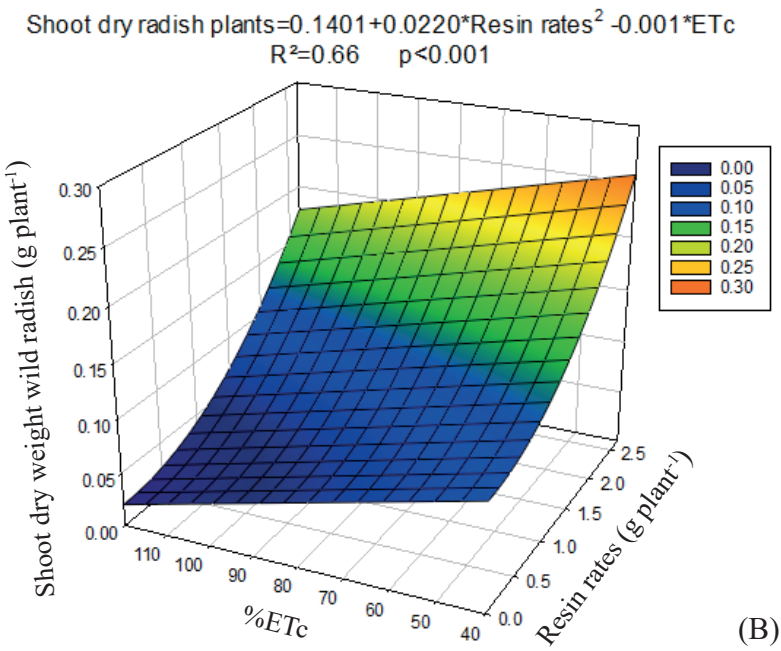

Root dry wild radish plants $=0.3316+0.2133^{*}$ Resin rates ${ }^{2}-$ $-0.0014^{*} \mathrm{ETc}-0.0030^{*} \mathrm{Resin}$ rates ${ }^{*} \mathrm{ETC}$

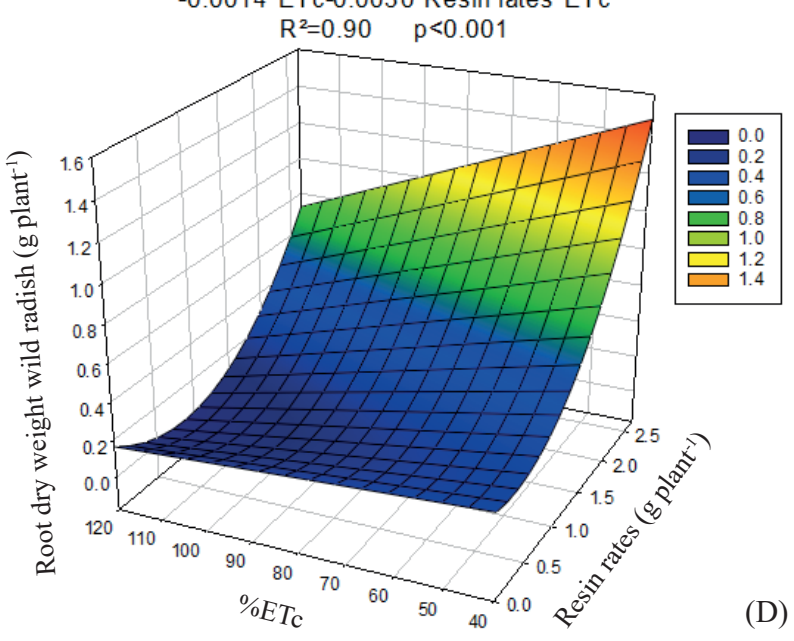

Figure 4. Shoot dry weight of cotton (A) and wild radish (B) plants and root dry weight of cotton (C) and wild radish (D) plants, as a function of resin rates and evapotranspiration (ETc) (wild radish) and soil water tensions (cotton). 

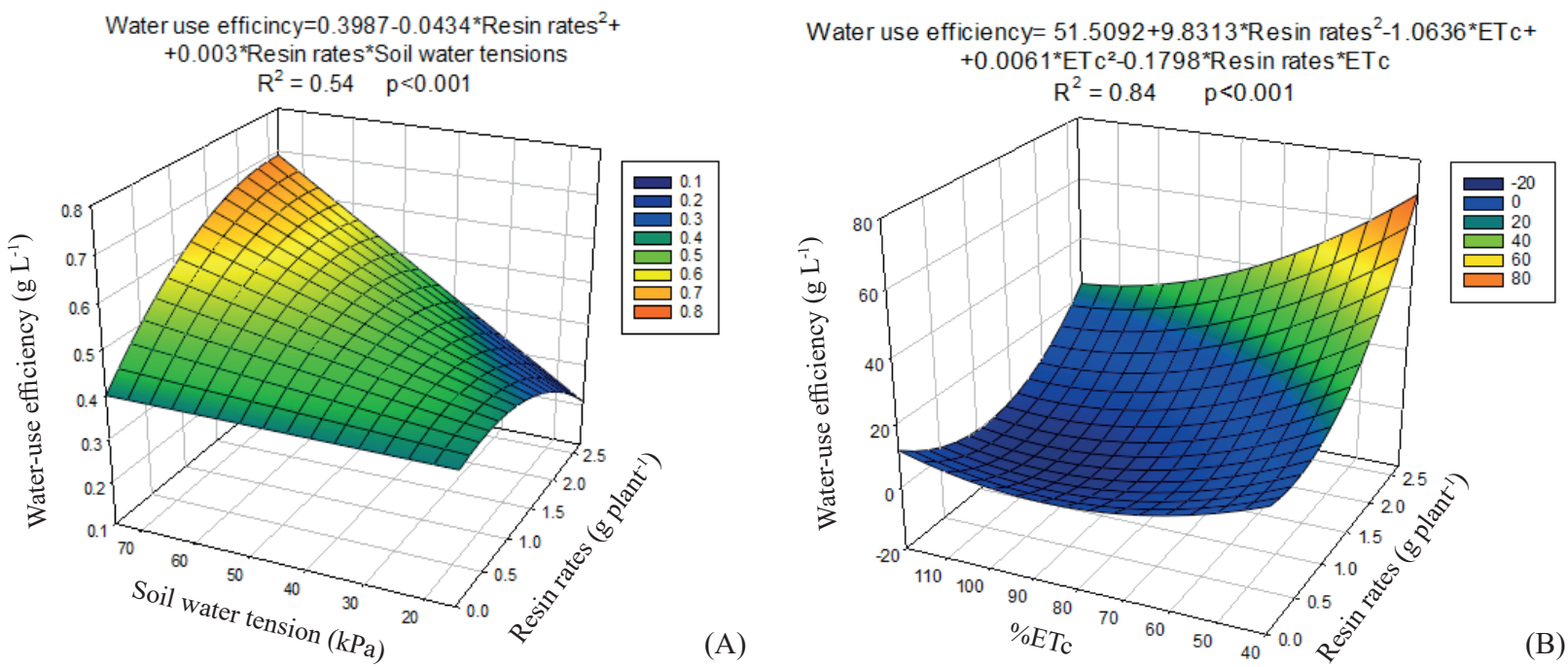

Figure 5. Water-use efficiency of cotton (A) and wild radish (B) plants, as a function of tree resin rates (g plant $\left.{ }^{-1}\right)$ and evapotranspiration (ETc) (wild radish) and soil water tensions (cotton).

The cotton and wild radish plants presented a better development when using the resin rate of $2.7 \mathrm{~g} \mathrm{plant}^{-1}$ and the highest soil water tension (75 $\mathrm{kPa}$ ) for the cotton and the lowest evapotranspiration $(40 \%)$ for the wild radish plants. This is due to the higher water availability to plants enabled by the plant polymer.

Thus, the application of resin resulted in plants with higher shoot and root dry weights. Carvalho et al. (2011) found similar results for the application of hydrogel in coffee plants, with a higher plant height, stem diameter, shoot and root dry weights, and leaf area.

The main advantage of using water-retaining polymers is their capacity to absorb and store water. The use of these products improves the soil water availability and other soil properties, such as porosity and water storage capacity, and decreases losses of nutrients by percolation and leaching, improving the plant development throughout the plant cycle (Albuquerque Filho et al. 2009), as shown by the results found in the present study.

The use of adequate irrigation management and tree resin application are options that favor the water economy and water-use efficiency and decrease environmental problems and water consumption, what is shown by the increases found for water-use efficiency (Figures 5A and 5B). The highest wateruse efficiency was found in plants subjected to the highest resin rates and soil water tension $(75 \mathrm{kPa})$ for cotton plants $\left(0.68 \mathrm{~g} \mathrm{~L}^{-1}\right)$, and in those subjected to the lowest crop evapotranspiration (40\%) for wild radish plants $\left(69.6 \mathrm{~g} \mathrm{~L}^{-1}\right)$, which promoted a greater water economy (Figures 5A and 5B).

These results are probably due to organic compounds with high water retention capacity in the chemical composition of the plant polymer, which improve the water absorption capacity. According to López-Elías et al. (2016), these compounds in the polymer increase the water-use efficiency.

Oweis et al. (2011) found a higher water-use efficiency for cotton plants in treatments under full irrigation, when compared to plants in treatments under water deficit, in Syria. The findings of the present study contrast with that result, since the highest water-use efficiency was found in cotton plants under water deficit, due to the maintenance of soil moisture by the resin, which improved the plant performance (Figure 5A).

Further studies should evaluate the effects of polymerization, allelopathy and extraction processes of tree resin to better define the potential of this new material to decrease the water deficit in cultivated plants.

\section{CONCLUSIONS}

1. The application of resin from silk floss tree [Ceiba speciosa (A. St.-Hil.) Ravenna] to the soil reduces the susceptibility of cotton and wild radish plants to water deficit;

2. The highest recommended resin rate to obtain better plant developments under similar conditions 
to those evaluated in the present study is 2.7 g plant $^{-1}$;

3. The use of tree resin increases the water-use efficiency of cotton and wild radish plants in up to $0.68 \mathrm{~g} \mathrm{~L}^{-1}$ and $69.6 \mathrm{~g} \mathrm{~L}^{-1}$, respectively.

\section{ACKNOWLEDGMENTS}

The authors would also like to thank the Fundação de Amparo à Pesquisa do Estado de Minas Gerais (Fapemig), Coordenação de Aperfeiçoamento de Pessoal de Nível Superior (Capes, Financial Code 001) and Conselho Nacional de Desenvolvimento Científico e Tecnológico ( $\mathrm{CNPq})$, for the financial support and scholarships granted.

\section{REFERENCES}

ALBUQUERQUE FILHO, J. A. C.; LIMA, V. L. A.; MENEZES, D.; AZEVEDO, C. A. V.; DANTAS NETO, J.; SILVA JÚNIOR, J. G. Características vegetativas do coentro submetido a doses do polímero hidroabsorvente e lâminas de irrigação. Revista Brasileira de Engenharia Agrícola e Ambiental, v. 13, n. 6, p. 671-679, 2009.

ALLEN, R. G.; PEREIRA, L. S.; RAES, D.; SMITH, M. Evapotranspiración del cultivo: guías para la determinación de los requerimientos de agua de los cultivos. Rome: FAO, 2006.

ALVAREZ V., V. H.; RIBEIRO, A. C. Recomendação para o uso de corretivos e fertilizantes em Minas Gerais: $5^{a}$ aproximação. Viçosa: CFSEMG, 1999.

ALVES, E. S.; LIMA, D. F.; BARRETO, J. A. S.; SANTOS, D. P.; SANTOS, M. A. L. Competição de variedades de algodão herbáceo para cultivo no agreste pernambucano. Pesquisa Agropecuária Pernambucana, v. 24, n. 1, p. 1-8, 2019.

AZEVEDO, T. L. F.; BERTONHA, A.; GONÇALVES, A. C. A.; FREITAS, P. S. L.; REZENDE, R.; FRIZZONE, A. A. Uso de hidrogel na agricultura. Revista do Programa de Ciências Agro-Ambientais, v. 1, n. 1, p. 23-31, 2002.

BAHRAM, M.; MOHSENI, N.; MOGHTADER, M. An introduction to hydrogels and some recent applications. In: MAJEE, S. B. (ed.). Emerging concepts in analysis and applications of hydrogels. Rijeka: InTech, 2016. p. 9-38.

BERNARDO, S.; MANTOVANI, E. C.; SILVA, D. D. da; SOARES, A. A. Manual de irrigação. 9. ed. Viçosa: UFV, 2019.

BRASIL. Agência Nacional de Águas. Manual de usos consuntivos da água no Brasil. Brasília, DF: ANA, 2019.
CARVALHO, J. A.; AQUINO, R. F.; MESQUITA, G. L.; REZENDE, F. C.; PEREIRA, G. Utilização de polímero hidrorretentor no plantio de mudas de cafeeiro. Engenharia na Agricultura REVENG, v. 19, n. 2, p. 164-171, 2011.

CAUlfield, J.; QIAO, G. G.; SOlOMON, D. Degradation on polyacrylamides: part I. Linear polyacrylamide. Polymer, v. 44, n. 5, p. 1331-1337, 2003.

COELHO, J. B. M.; BARROS, M. F. C.; CORREA, M. M.; WANDERLEY, R. A.; COELHO JÚNIOR, J. M.; FIGUEREDO, J. L. C. Efeito do polímero hidratassolo sobre propriedades físico-hídricas de três solos. Revista Brasileira de Ciências Agrárias, v. 3, n. 3, p. 253-259, 2008.

CORDÃO SOBRINHO, F. P.; FERNANDES, P. D.; BELTRÃO, N. E. de M.; SOARES, F. A. L.; TERCEIRO NETO, C. P. C. Crescimento e rendimento do algodoeiro BRS-200 com aplicações de cloreto de mepiquat e lâminas de irrigação. Revista Brasileira de Engenharia Agrícola e Ambiental, v. 11, n. 3, p. 284-292, 2007.

ELOY, E.; CARON, B. O.; SCHMIDT, D.; BEHLING, A.; SCHWERS, L.; ELLI, E. F. Avaliação da qualidade de mudas de Eucalyptus grandis utilizando parâmetros morfológicos. Revista Floresta, v. 43, n. 3, p. 373-384, 2013.

FAN, R.; LUO, J.; YAN, S.; ZHOU, Y.; ZHANG, Z. Effects of biochar and superabsorbent polymer on substrate properties and water spinach growth. Pedosphere, v. 25, n. 5, p. 737-748, 2015.

FERREIRA, D. F. Sisvar: a computer analysis system to fixed effects split plot type designs. Revista Brasileira de Biometria, v. 37, n. 4, p. 529-535, 2019.

FLOWERS, T. J.; MUNNS, R.; COLMER, T. D. Sodium chloride toxicity and the cellular basis of salt tolerance in halophytes. Annals of Botany, v. 115, n. 3, p. 419-431, 2014.

HAFLE, O. M.; CRUZ, M. C. M.; RAMOS, J. D.; RAMOS, O. S.; SANTOS, V. A. Produção de mudas de maracujazeiro-doce através da estaquia utilizando polímero hidroretentor. Revista Brasileira de Ciências Agrárias, v. 3, n. 3, p. 232-236, 2008.

LOPES, M. B. S.; TAVARES, T. C. O.; VELOSO, D. A.; SILVA, N. C.; FIDELIS, R. R. Cowpea bean production under water stress using hydrogels. Pesquisa Agropecuária Tropical, v. 47, n. 1, p. 87-92, 2017.

LÓPEZ-ELÍAS, J.; GARZA, O. S.; JIMÉNEZ, L. J.; HUEZ, L. M. A.; GARRIDO, L. O. D. Uso de un polímero hidrófilo a base de poliacrilamida para mejorar la eficiencia en el uso del agua. European Scientific Journal, v. 12, n. 15 , p. 160-175, 2016.

M'BARKI, N.; AISSAOUI, F.; CHEHAB, H.; DABBAGHI, O.; GIUDICE, T.; BOUJNAH, D.; 
MECHRI, B. Cultivar dependent impact of soil amendment with water retaining polymer on olive (Olea europaea L.) under two water regimes. Agricultural Water Management, v. 216, n. 1, p. 70-75, 2019.

MARIANO-TORRES, J. A.; LÓPEZ-MARURE, A.; DOMIGUEZ-SÁNCHEZ, M. Á. Synthesis and characterization of polymers based on citric acid and glycerol: its application in non-biodegradable polymers. DYNA, v. 82, n. 190, p. 53-59, 2015.

MENDONÇA, T. G.; URBANO, V. R.; PERES, J. G.; SOUZA, C. F. Hidrogel como alternativa no aumento da capacidade de armazenamento de água no solo. Water Resources and Irrigation Management, v. 2, n. 2, p. 8792, 2013.

NELSON, D. L.; COX, M. M. Principios de bioquímica de Lehninger. 7. ed. Porto Alegre: Artmed, 2018.

OLIVEIRA, G. Q. de; BISCARO, G. A.; MOTOMIYA, A. V. de A.; JESUS, M. P. de.; VIEIRA FILHO, P. S. V. Aspectos produtivos do rabanete em função da adubação nitrogenada com e sem hidrogel. Journal of Agronomic Sciences, v. 3, n. 1, p. 89-100, 2014.

OWEIS, T. Y.; FARAHANI, H. J.; HACHUM, A. Y. Evapotranspiration and water use of full and deficit irrigated cotton in the Mediterranean environment in northern Syria. Agricultural Water Management, v. 98, n. 8, p. 1239-1248, 2011.

PASSAUER, L.; HALLAS, T.; BÄUCKER, E.; CIESIELSKI, G.; LEBIODA, S.; HAMER, U. Biodegradation of hydrogels from oxyethylated lignins in model soils. ACS Sustainable Chemistry \& Engineering, v. 3, n. 9, p. 1955-1964, 2015.
RODRIGUES, R. C. Métodos de análises bromatológicas de alimentos: métodos físicos, químicos e bromatológicos. Pelotas: Embrapa Clima Temperado, 2010.

RODRIGUEZ, F.; COHEN, C.; OBER, C. K.; ARCHER, L. A. Principles of polymer systems. 6. ed. Boca Raton: CRC, 2014.

SILVA, M. B. R.; FERNANDES, P. D.; DANTAS NETO, J.; NERY, A. R.; RODRIGUES, L. N.; VIÉGAS, R. A. Crescimento e produção do pinhão-manso irrigado com água residuária sob condições de estresse hídrico. Revista Brasileira de Engenharia Agricola e Ambiental, v. 15, n. 6, p. 621-629, 2011.

SILVA, A. F. A.; SOUZA, Ê. G. F.; BARROS JÚNIOR, A. P.; BEZERRA NETO, F.; SILVEIRA, L. M. Desempenho agronômico do rabanete adubado com Calotropis procera (Ait.) R. Br. em duas épocas de cultivo. Revista Ciência Agronômica, v. 48, n. 2, p. 328-336, 2017.

UNITED STATES DEPARTMENT OF AGRICULTURE (USDA). Soil Survey Staff. Keys to soil taxonomy. 12. ed. Washington, DC: USDA, 2014.

VILLES, V. S.; VELHO, J. P.; CHRISTOFARI, L. F.; LAZZARI, R. Água como bem econômico: dessalinização para o combate da escassez hídrica no agronegócio. Multitemas, v. 24, n. 57, p. 217-231, 2019.

ZOMERFELD, P. S.; LIMA, N. B.; BISCARO, G. A.; MOTOMIYA, A. V. A.; BORELLI, A. B.; MONACOMELLO, K. A.; PAGLIARINI, M. K. Radish cultivation with hydrogel doses combined with different water slides in drip irrigation system. Research, Society and Development, v. 10, n. 4, e54810414394, 2021. 